\title{
Faktor-faktor penyebab pernikahan dini di Desa Banjar Balam Kecamatan Lirik Kabupaten Indragiri Hulu Provinsi Riau
}

\author{
Yulia Ulan Dari ${ }^{1}$, Triwahyuningsih ${ }^{2}$ \\ ${ }^{1}$ Program Studi PPKn, Universitas Ahmad Dahlan, Yogyakarta \\ ${ }^{2}$ Program Studi PPKn, Universitas Ahmad Dahlan, Yogyakarta \\ a yulia1500009004@webmail.uad.ac.id ${ }^{b}$ triwahyuningsih@ppkn.uad.ac.id
}

\begin{abstract}
ABSTRAK
Banyaknya pernikahan dini yang terjadi di Desa Banjar Balam dari kondisi demografi masyarakat berdasarkan mata pencarian sebagian besar adalah petani, kemudian berdasarkan tingkat pendidikan masyarakat Desa Banjar Balam kebanyakan hanya tamatan Sekolah Dasar (SD). Tujuan penelitian ini adalah untuk mengetahui faktor-faktor penyebab pernikahan dini di Desa Banjar Balam Kecamatan Lirik Kabupaten Indragiri Hulu Provinsi Riau tahun 2017-2018. Penelitian ini merupakan jenis pendekatan deskriptif dan menggunakan metode penelitian kualitatif. Subjek dalam penelitian ini adalah remaja (pelaku pernikahan dini), orang tua, kepala desa, kepala urusan agama kecamatan lirik, dan tokoh masyarakat. Sedangkan objek dalam penelitian ini adalah faktor-faktor penyebab pernikahan dini. Pengumpulan data dilakukan dengan cara observasi, wawancara dan dokumentasi. Teknik analisis data yang digunakan adalah validasi, reduksi data, penyajian data, dan penarikan kesimpulan. Hasil penelitian menunjukkan bahwa faktor-faktor penyebab pernikahan dini di Desa Banjar Balam Kecamatan Lirik Kabupaten Indragiri Hulu Provinsi Riau tahun 2017-2018 di sebabkan oleh faktor ekonomi, faktor pergaulan sosial, faktor pendidikan dan faktor budaya.
\end{abstract}

Kata kunci: Faktor-faktor penyebab, Pernikahan dini

\section{PENDAHULUAN}

Indonesia merupakan Negara yang terjadi peningkatan pertumbuhan penduduk yang cepat jumlahnya, dengan peningkatan tersebut tentu didorong dengan faktor tertentu dalam kehidupan sehari-hari seperti ekonomi, sosial, agama, psikologi dan budaya. Sebagai negara berkembang tentunya Indonesia memilki angka pernikahan yang cukup tinggi, sehingga sering kali terjadi perkawinan dibawah umur. Menurut UNICEF, bahwa satu dari enam anak perempuan di Indonesia menikah sebelum usia 18 tahun. Sehingga sering terjadi pernikahan dini terutama di daerah perdesaan.Pernikahan dini sering terjadi di daerah-daerah perdesaan, sehingga memiliki faktor-faktor penyebab, Perkawinan menurut Undang-Undang Nomor 1 Tahun 1974 ialah "katan lahir bathin antara seorang pria dengan seorang wanita sebagai suami istri dengan tujuan membentuk keluarga (rumah tangga) yang bahagia dan kekal berdasarkan Ketuhanan Yang Maha Esa".

Beberapa waktu terakhir ini pernikahan dini di Indonesia semakin banyak, apalagi di daerah-daerah perdesaan. Berdasarkan (BKKBN 2015), jumlah penduduk Indonesia akan mencapai 271 juta jiwa pada tahun 2020. Jika dibandingkan dengan sekarang jumlah penduduk yang meningkat, menyebabkan banyak faktor yang terjadi yaitu tingginya tingkat moralitas dengan usia perkawinan yang rendah. Salah satu cara untuk mengendalikan guncangan jumlah penduduk adalah dengan cara penundaan usia perkawinan. Berdasarkan umur perkawinan pertama yang ideal bagi perempuan adalah 21-25 tahun, sedangkan laki-laki usia 25-28 tahun. Semakin rendah umur perkawinan pertama atau semakin tinggi perempuan semakin besar risiko yang dihadapi selama masa kehamilan dan proses melahirkan. Hal ini disebabkan belum matangnya kondisi perempuan baik secara fisik maupun psikologis. Sementara itu, semakin tinggi umur perkawinan pertama bagi perempuan dikhawatirkan masa subur perempuan juga semakin berkurang. Menurut UndangUndang Nomor 35 Tahun 2014 tentang, perlindungan anak bahkan masih belum genap berusia 18 tahun. Pada masa usia tersebut seharusnya mereka masih berhak merasakan serunya bermain bersama temanteman, menikmati indahnya masa remaja, belajar, mengaktualisasikan bakatnya, serta mendapat kasih sayang dan perlindungan dari orang tua. Perkawinan anak dapat membawa anak ke "dunia dewasa" secara prematur.

Menurut Rosalin (2018), Deputi Tumbuh Kembang Anak Kementrian PPPA selain berdampak terhadap pendidikan, perkawinan anak juga memiliki dampak yang penting terhadap kesehatan ibu dan anak, serta ekonomi. Kemudian masalah kesehatan, baik dari ibu maupun anaknya ketika melahirkan akan 
terkena risiko pendarahan, bahkan kematian. Ketiga masalah ekonomi, jika dalam usia anak-anak mereka telah menjadi janda yang telah memiliki anak, maka anak tersebut harus bekerja untuk menghidupi anaknya. Selain itu, pada umumnya mereka hanya memiliki ijazah tingkat sekolah dasar dan memiliki upah yang rendah, sehingga dapat menyebabkan terjadinya kemiskinan.

Komitmen dunia untuk mengakhiri perkawinan anak sebenarnya telah dibuktikan dengan salah satu target Sustainable Development Goals (SDDGs) tujuan ke 5 target ke 3 indikator ke 1 berbicara tentang proporsi perempuan umur 20-24 tahun yang berstatus kawin sebelum umur 15 tahun dan sebelum umur 18 tahun. Perkawinan pada anak juga mencerminkan rendahnya status perempuan. Studi yang dilakukan UNICEF menyatakan bahwa perkawinan anak sering terjadi pada perempuan yang memiliki pendidikan rendah dan rentan terhadap tindakan kekerasan dalam rumah tangga. Padahal, seorang anak adalah harapan terbesar orang tua, dan praktik perkawinan anak telah memadamkan api harapan tersebut.

Kementerian Pemberdayaan Perempuan dan Perlindungan Anak (PPPA) bekerja sama dengan Badan Pusat Statistik (BPS) pada tahun 2016 telah mengumpulkan informasi mengenai jenjang pendidikan yang ditempuh oleh perempuan usia 20-24 tahun berstatus pernah kawin yang melakukan perkawinan di bawah atau di atas 18 tahun. Hasilnya cukup memprihatinkan, sebesar 94,72\% perempuan usia 20-24 tahun berstatus pernah kawin yang melakukan perkawinan di bawah umur 18 tahun atau usia anak tidak bersekolah lagi, sementara yang masih bersekolah hanya sebesar $4,38 \%$.

Perempuan usia 20-24 tahun berstatus pernah kawin yang melakukan perkawinan pada usia anak pun cenderung memiliki pendidikan yang lebih rendah dibandingkan dengan mereka yang kawin di atas usia 18 tahun. Perempuan usia 20-24 tahun berstatus pernah kawin pada usia anak paling tinggi hanya menyelesaikan Sekolah Dasar (SD) hingga Sekolah Menengah Pertama (SMP), yakni sebesar 42,11\%, dan yang menyelesaikan jenjang Sekolah Menengah Atas (SMA) hanya 11,54\%. Sedangkan yang melakukan perkawinan di atas usia 18 tahun mayoritas menyelesaikan pendidikannya hingga ke jenjang SMA, yakni sebesar $45,89 \%$.

Karena menikah pada usia anak, maka mereka tidak dapat lagi memperoleh hak atas pendidikan. Padahal, selain bisa menjadi tangga bagi masyarakat untuk mengubah status sosial mereka, pendidikan merupakan hal terpenting untuk membentuk kepribadian, mendapatkan pengalaman, dan membentuk generasi bangsa yang cemerlang.Adapun pertimbangan MK mengenai pernikahan anak di Indonesia yang semakin meningkat. Hal itu dilihat dari data BPS tahun 2017. Sebaran angka perkawinan anak di atas 25 persen berada di 23 provinsi dari 34 provinsi di Indonesia. Menurut Anawar mengenai putusan MK ialah sebagai berikut:

"Kondisi ini tentu sangat mengkhawatirkan karena anak telah kehilangan hak-hak yang seharusnya dilindungi oleh negara. Jika kondisi ini dibiarkan tentu akan menjadikan Indonesia berada dalam kondisi 'Darurat Perkawinan Anak', dan tentu saja akan semakin menghambat capaian tujuan bernegara sebagaimana termasuk dalam Pembukaan UUD 1945,". (Christofours Ristianto, 03/06/2019)

Sementara itu dalam upaya mencegah kekerasan terhadap anak termasuk perkawinan anak, Kementerian Pemberdayaan Perempuan dan Perlindungan Anak mendorong adanya perlindungan anak berbasis masyarakat. Sebab, salah satu faktor terbesar yang mendorong anak menikah pada usia muda ialah lingkungannya termasuk keluarga. Kemudian, perlu adanya sinergi dengan pemangku kepentingan lain. Banyak terjadi kekerasan terhadap anak di lingkungan masyarakat. Keluarga punya peran kuat melindungi anaknya dari berbagai pergaulan bebas.

Faktanya di lapangan menunjukkan bahwa angka perkawinan muda sangat tinggi, menurut Data Statistik Proporsi (DSP) Perempuan Umur 20-24 yang berstatus kawin atau berstatus hidup bersama sebelum umur 15 tahun menurut provinsi (persen) tahun 2015-2017 bahwa provinsi Riau mengalami peningkatan dari tahun ke tahun yaitu pada tahun 2015; $0.22 \%$, tahun $2016 ; 0.57 \%$ dan pada tahun 2017; 1.01\%. (Profil Desa Banjar Balam, 12/06/2019).

Umumnya pernikahan dilakukan oleh wanita dan laki-laki yang usianya cukup dewasa untuk menikah, seperti ketentuan batas usia dalam Undang-Undang No.1 Tahun 1974 Pasal 7 ayat (1) yang menjelaskan bahwa: "Perkawinan hanya diizinkan bila pihak laki-laki mencapai usia 19 (sembilan belas) tahun dan pihak perempuan sudah mencapai usia 16 (enam belas) tahun".

Menurut MK, ketika Pasal 7 ayat (1) UU 1/1974 disusun dan dibahas, penentuan batas usia merupakan salah satu bentuk kesepakatan nasional yang telah disepakati setelah mempertimbangkan secara bijaksana dan memperhatikan nilai-nilai yang berlaku pada saat undang-undang disusun yang kemudian disahkan pada 1974. Namun, dalam perkembangan ketatanegaraan Indonesia, yang ditandai dengan 
diubahnya UUD 1945 (1999-2002), terjadi penguatan terhadap jaminan dan perlindungan hak asasi manusia dalam konstitusi dengan dicantumkannya pasal-pasal tentang jaminan hak asasi manusia, termasuk hak untuk membentuk keluarga dan hak anak. Jaminan dan perlindungan hak asasi manusia yang dimaksud juga merupakan kesepakatan nasional, bahkan dirumuskan secara tegas dalam Konstitusi.

Berdasarkan pembedaan batas usia minimum perkawinan yang telah menyebabkan perempuan menjadi diperlakukan berbeda dengan laki-laki dalam pemenuhan hak-hak konstitusionalnya, baik hak-hak sipil dan politik maupun hak-hak ekonomi, sosial, dan kebudayaan, semata-mata karena jenis kelaminnya. Sedangkan dalam hal lain perlindungan anak yang mengandung perlakuan berbeda atas dasar ras, agama, suku, warna kulit, dan jenis kelamin, maka sudah seharusnya pula untuk disesuaikan dengan kehendak UUD 1945 yang anti-diskriminasi. Salah satu kebijakan hukum yang dapat dikategorikan mengandung perlakuan berbeda atas dasar jenis kelamin dimaksud adalah Pasal 7 ayat 1 Undang-Undang Tahun 1974.

Berdasarkan ketentuan pernikahan, jika dilakukan sebelum usia dari aturan dalam Undang-Undang maka disebut dengan pernikahan dibawah umur atau pernikahan dini. Di sisi lain ditegaskan pula dalam UU No. 23 Tahun 2002 tentang Perlindungan Anak, bahwa individu yang belum berusia 18 tahun, termasuk anak yang masih di dalam kandungan masih dikategorikan sebagai anak. Anak adalah bagian yang tidak terpisahkan dari keberlangsungan hidup manusia dan keberlangsungan sebuah bangsa dan negara. agar kelak mampu bertanggung jawab dalam keberlangsungan bangsa dan negara, setiap anak perlu mendapat kesempatan yang seluas-luasnya untuk tumbuh dan berkembang secara optimal, baik fisik, mental, maupun sosial.

Pemerintah belum punya kebijakan terhadap anak dibawah umur untuk meminimalisasikan pernikahan dini, berhubung anak sebagai tunas, potensi, dan generasi muda penerus cita-cita perjuangan bangsa memiliki peran strategis, ciri, dan sifat khusus sehingga wajib dilindungi dari segala bentuk perlakuan tidak manusiawi yang mengakibatkan terjadinya pelanggaran hak asasi manusia.

Keterlibatan Negara dalam menjunjung tinggi hak asasi manusia, termasuk di dalamnya hak asasi anak yang ditandai dengan adanya jaminan perlindungan dan pemenuhan hak asasi anak dalam Undang-Undang Dasar Negara Republik Indonesia Tahun 1945 dan beberapa ketentuan peraturan perundang-undangan baik yang bersifat nasional konvensi international tentang Hak Asasi Anak yaitu, pengesahan Konvensi Hak Anak melalui Keputusan Presiden Nomor 36 tahun 1990 tentang pengesahan Convention On The Rights Of The Child (Konvensi Tentang Hak-hak Anak)

Berdasarkan tugas pemerintah dalam hak dan kewajiban untuk memberikan perlindungan dan menjamin terpenuhinya hak asasi anak sesuai dengan tugas dan tanggung jawabnya. Perlindungan terhadap anak yang dilakukan selama ini belum memberikan jaminan bagi anak untuk mendapatkan perlakuan dan kesempatan yang sesuai dengan kebutuhannya dalam berbagai bidang kehidupan, sehingga dalam melaksanakan upaya perlindungan terhadap hak anak oleh pemerintah harus didasarkan pada prinsip hak asasi manusia yaitu penghormatan, pemenuhan, dan perlindungan atas hak anak.

Menurut Soekanto (2012), pernikahan adalah suatu kehidupan yang dapat dilihat dari faktor sosial budaya, ekonomi, dan pendidikan. yang dilandasi oleh kebiasaan dalam kehidupan sehari-hari menjadi suatu gejala yang menyebabkan terjadinya pernikahan dini. Sehingga tingkat kebutuhan ekonomi yang rendah, keadaan ekonomi keluarga yang minim akan menyebabkan orang tua menikahkan anak perempuannya dengan orang yang dianggapnya mampu untuk meringankan beban ekonomi keluarga.

Permasalahan pernikahan dini menjadi sangat penting untuk diperhatikan, bahkan ada suatu desa di Indonesia yang sangat merespons positif terhadap pernikahan dini ini. Karena mereka beranggapan bahwa pernikahan dini adalah suatu tradisi dari nenek moyang yang harus dilestarikan secara turun temurun menurun Selain itu karena faktor kemauan sendiri, anak perempuan dan anak laki-laki yang merasa sudah saling mencintai akan terpengaruh dan termotivasi untuk menikah di usia dini.

\section{METODE PENELITIAN}

Jenis penelitian yang digunakan adalah kualitatif dengan menggunakan pendekatan deskriptif, alasannya karena faktor-faktor penyebab pernikahan dini dapat digambarkan deskriptif. Oleh karena itu menggunakan deskriptif agar terlihat gambaran elemen yang berkontribusi dalam kenakalan remaja seperti faktor kenakalan, bentuk kenakalan dan subjek yang jelas seperti remaja.

Metode penelitian kualitatif dapat diartikan sebagai metode penelitian yang berlandaskan pada filsafat pos positivisme, digunakan untuk meneliti pada kondisi objek yang alamiah, peneliti sebagai instrumen 
kunci, teknik pengumpulan data dilakukan secara triangulasi (gabungan), analisis data bersifat deskriptif kualitatif, hasil peneliti kualitatif lebih menekankan makna dari generalisasi dalam Sugiyono, 2017.

Penelitian ini dilakukan pada objek alamiah, yaitu di Desa Banjar Balam Kecamatan Lirik Kabupaten Indragiri Hulu Provinsi Riau. Teknik pengumpulan data melalui observasi, wawancara, dan dokumentasi. Instrumen peneliti adalah peneliti sendiri.

\section{HASIL DAN PEMBAHASAN}

\section{Faktor-faktor penyebab pernikahan dini yang terdapat di Desa Banjar Balam Kecamatan Lirik Kabupaten Indragiri Hulu Provinsi Riau}

Pernikahan dini pada umumnya merupakan hal yang biasa pada zaman sekarang, umumnya anakanak yang menginjak usia dewasa akan berkembang dengan kondisi fisik, mentalitas dan sosialnya. Mereka bergaul dengan teman-temannya yang manakala dalam pergaulan itu mereka menemukan pasangan yang dirasanya sesuai untuk dirinya. Perubahan pergaulan yang akrab tersebut kemudian menumbuhkan rasa cinta. Yang pada akhirnya ke duanya menginginkan pernikahan.

Masyarakat yang berdomisili di Desa Banjar Balam Kecamatan lirik Kabupaten Indragiri Hulu Provinsi Riau umumnya adalah masyarakat suku Melayu yang memiliki pandangan bahwa bermula dari sentuhan pandangan antar lelaki (anak bujang) dengan perempuan (anak gadis). Tetapi, juga bisa terjadi pandangan ibu/bapak atau kaum kerabat yang berminat untuk mencarikan jodoh anaknya. Bila seorang anak bujang memberitahukan gadis pujaannya kepada ibu/bapaknya maupun kaum kerabat memandang ada seorang anak gadis yang patut menjadi jodoh anaknya, maka pihak keluarga lelaki mulailah melakukan semacam kegiatan yang bernama meresik (meminang).

Pernikahan dini tidak dapat di hindari, entah karena faktor ekonomi, pendidikan, sosial, dan budaya maupun hal-hal yang tidak diinginkan. Lurah Desa Banjar Balam mengatakan: "orang yang melakukan pernikahan dini memiliki alasan masing-masing, entah karena faktor ekonomi keluarga, pendidikan maupun hal-hal yang tidak diinginkan. Beliau merasa prihatin kalau pelaku nikah dini putus sekolah, jadi seolah-olah anak tidak bisa melanjutkan cita-citanya"

Berdasarkan kutipan diatas, lurah Desa Banjar Balam mengatakan pernikahan dini dilakukan dengan berbagai alasan, yang beliau sayangkan karena setelah menikah anak senantiasa putus sekolah.

Masalah yang timbul dari pernikahan dini tidak hanya dirasakan suami istri dan anak-anaknya, namun pernikahan di usia dini dapat berpengaruh terhadap orang tua masing-masing keluarga. Ada beberapa faktor pernikahan usia dini dijelaskan dibawah ini:

\section{Faktor Ekonomi}

Pernikahan dini terjadi karena perekonomian dalam keluarga yang tergolong kurang atau dalam garis kemiskinan. Demi meningkatkan beban orang tua, anak perempuannya dinikahkan dengan laki-laki yang dianggap mampu. Pengaruh ekonomi dalam masyarakat khususnya di Desa Banjar Balam kepada perjodohan anak mereka dari keluarga yang miskin dengan keluarga yang kaya dengan harapan akan terjamin masa depan anak mereka, ini memang merupakan faktor yang sangat berpengaruh dalam kasus pernikahan usia dini secara umum dan terkhusus di Desa Banjar Balam.

Hal ini didukung oleh Data Kependudukan di Kecamatan Lirik Tahun 2019 mayoritas adalah Petani sebanyak 290 orang, sedangkan sisanya adalah pedagang sebanyak 7 orang dan PNS sebanyak 4 orang (Kecamatan Lirik dalam penduduk menurut mata pencarian, 2019). Mayoritas masyarakat di Desa Banjar Balam berkebun kelapa sawit dan karet. Sebagaimana diketahui bahwa harga jual kelapa sawit dan karet mengalami kenaikan dan penurunan yang tidak menentu.

Tentunya kondisi ini membuat perekonomian masyarakat menjadi tidak stabil, apalagi kebun yang dimiliki tidak banyak. Ditambah lagi biaya hidup sehari-hari dan biaya sekolah anak semakin meningkat membuat para orang tua kesulitan dalam masalah ekonomi. Karena kesulitan ekonomi ini, maka remaja berfikir untuk segera menikah, sehingga remaja tersebut tidak tergantung pada orang tua lagi (mandiri).

Berdasarkan indikator Badan Pusat Statistik orang miskin memiliki penghasilan rata-rata dibawah Standar Nasional yaitu Rp. 4.600 .000 per bulan. Adapun tujuan pemerintah dalam mewujudkan masyarakat yang sejahtera seperti bantuan-bantuan terhadap orang miskin masih belum cukup membantu, sehingga orang tua bekerja untuk menghidupkan anak-anaknya saja. Tidak terlalu memikirkan masa depan anaknya pada jenjang pendidikan yang lebih tinggi 
Program Wajib belajar 12 tahun juga bagian dari upaya pemerintah menekankan pernikahan dini, tetapi orang tua juga harus diberi edukasi. Penyebab pernikahan dini di Desa banjar balam faktor ekonomi sangat dominan, orang tua juga menganggap dengan menikahkan anak akan mengurangi beban hidup. Kemudian pola pikir berkelanjutan di masyarakat yang menganggap menikahkan anak di usia dini merupakan hal wajar bahkan suatu keharusan karena tradisi.

Peran orang tua harusnya memberikan pemahaman mengenai akibat dari pernikahan dini, juga mengenai kesehatan reproduksi pada anaknya. Anak harus disibukkan dengan kegiatan berkreasi dan berprestasi agar terjauh dari hal-hal yang menyebabkan pernikahan dini. Sama halnya dengan hasil Informan SN: "Dengan menikah sedikit akan membantu mengurangi beban orang tua SN, setidaknya setelah menikah ada yang menanggung semua ekonomi saya, sehingga orang tua kurang terbebani"

Berdasarkan wawancara diatas SN beranggapan setelah menikah sedikit mengurangi beban orang tuanya, ada suami yang mengatur semua ekonomi. Menurut peneliti, orang tua informan pernikahan tersebut semata-mata hanya tujuan agar mereka bahagia dan lega karena sudah menikahkan anaknya. Selain itu penghasilan yang didapat dari informan SN: "Biasanya penghasilan suami per dua minggu 200 ribu sampai 300, kalau dikumpulkan sebulan ya sekitar 1.000.000."

Berdasarkan hasil wawancara dengan informan SN, bahwa penghasilan suaminya selama sebulan kurang lebih Rp. 1.000.000 per bulan. Jika di bandingkan dengan standar penghasilan nasional sangat jauh sekali. Sehingga menyebabkan informan untuk menikah agar beban orang tua menjadi ringan.

Ketika seseorang memilih untuk menikah dini maka sebaiknya mempersiapkan diri terlebih dahulu sehingga nantinya memiliki bekal untuk menjalin hidup berumah tangga serta menghindari dari kemungkinan-kemungkinan yang buruk. Seperti yang di ungkapkan Kepala Desa Banjar Balam: "Apabila anak yang ingin melakukan pernikahan di usia dini, sebaiknya memperhatikan hal-hal apa yang harus dilakukan sebelum menikah, contohnya mampu memenuhi tanggung jawab sebagai suami/istri, memiliki kematangan emosi sehingga dapat menyesuaikan diri".

Berdasarkan wawancara diatas, Kepala Desa Banjar Balam beranggapan bahwa sebelum menikah ada hal-hal yang harus diperhatikan, agar rumah tangga yang akan dijalani dapat berjalan dengan sakinah, mawaddah, warahmah.

Tingginya anak menikah di bawah umur di Desa Banjar balam disebabkan oleh faktor ekonomi yang berada di bawah garis kemiskinan, peran pemerintah sangat diperlukan untuk membentuk perekonomian masyarakat dengan menjalankan program pemerintah kepada desa lebih dioptimalkan lagi. Sehingga dapat meminimalisir faktor ekonomi yang menyebabkan sering terjadinya pernikahan dini di Desa Banjar Balam.

Jadi yang dimaksud dengan faktor ekonomi dari pernikahan dini di Desa Banjar Balam merupakan faktor paling dominan adalah ekonomi, karena mata pencarian terbesar masyarakat Desa Banjar Balam adalah petani. Penghasilannya dibawah standar nasional, sehingga termasuk dibawah garis kemiskinan yang menyebabkan banyak terjadinya pernikahan dini.

Kemudian dari kesimpulan di atas dapat dikaitkan dengan teori menurut Sahara (2018), bahwa perkawinan usia muda terjadi karena keadaan keluarga yang hidup pada garis kemiskinan, untuk meringankan beban orang tuanya maka anak wanitanya dikawinkan dengan orang yang dianggap mampu. Teori tersebut cocok dengan realita yang ada di Desa Banjar Balam dan saling berkesinambungan.

\section{Faktor Pergaulan Sosial}

Faktor sosial merupakan penyebab dari kebiasaan atau pergaulan bebas yang sering terjadi dalam kehidupan sehari-hari, masih ada beberapa remaja yang menikah di usia dini sebagai akibat dari pergaulan bebas, seperti yang terjadi di Desa Banjar Balam

Dalam kehidupan bermasyarakat tentu memiliki aturan atau norma-norma yang berlaku di masyarakat seperti norma agama, norma hukum. Agar manusia takwa kepada Tuhan maka tidak ada manusia yang mempunyai sikap batin yang buruk, tidak ada rencana berbuat jahat, hubungan antara anggota masyarakat baik, masyarakat menjadi tertib dengan ras keadilan, maka tujuan hukum tercapai

Bahwa dalam norma kesusilaan memiliki kaitan yang erat dengan kebiasaan yang ada di dalam masyarakat, jika dilanggar akan berakibat negatif seperti dikucilkan, dipandang rendah oleh masyarakat. Setiap pribadi manusia tentu memiliki hati nurani, sehingga manusia itu ingin berbuat yang baik, maka pribadi-pribadi manusia yang hidup bersama tidak menimbulkan sesuatu yang tercela, akhirnya kehidupan dalam masyarakat tertib dan damai. 
Pergaulan bebas biasanya dilihat dari pergaulan antar teman sejawat yang menyebabkan saling menyukai dan berpacaran, mereka menganggap bahwa apa pun yang dilakukan oleh muda mudi yang berpacaran adalah hal yang biasa meskipun terkadang pergaulan mereka sudah melewati batas. Bahkan sebagai orang tua tidak merasa malu kalau anaknya menikah karena sudah hamil di luar nikah. Seperti wawancara dengan informan IF yang menikah karena hamil di luar nikah sebagai berikut: "Sebenarnya saya sangat menyesal sudah bergaul terlalu bebas, saya sering berbohong sama orang tua saya, alasan mau mengerjakan tugas kelompok tetapi saya pergi bersama pacar saya. Dan kami saling menyayangi sehingga kami melakukan suatu hubungan terlarang."

Berdasarkan hasil wawancara dengan informan IF bahwa, dikarenakan pergaulan bebas yang awalnya saling tertarik dan timbul rasa sayang menyebabkan ia memberikan segalanya agar pacarnya percaya kalau informan IF benar menyayanginya sehingga mengakibatkan hamil diluar nikah dan tidak bisa melanjutkan pendidikannya.

Pernikahan dini mempunyai pengaruh besar terhadap tingginya angka kematian ibu, bayi dan umur harapan hidup, yaitu kesakitan dan kematian ibu di usia muda serta kesakitan dan kematian anak-anaknya relatif lebih tinggi dari usia ibu lainnya, bahkan pengaruh terhadap pendidikan anak dan kemampuan pembentukan keluarga sehat sejahtera. Penelitian dan pengalaman di berbagai negara, baik negara maju maupun berkembang termasuk indonesia, menunjukkan bahwa perkawinan usia dini mempunyai dampak negatif, salah satunya bila seorang anak perempuan hamil di usia 19 tahun ke bawah, dia tidak akan mendapat asupan gizi yang cukup karena harus berbagi dengan bayi dalam kandungannya. Hal itu berkaitan pada tingginya angka kematian ibu (AKI) dan angka kematian bayi (AKB).

Pada umumnya, pernikahan dini belum memiliki kematangan jiwa dalam melangsungkan perkawinan, sehingga apabila mereka nikah, maka antara suami istri tersebut tidak dapat menjalankan hak dan kewajibannya sebagai suami istri di dalam hidup berumah tangga, dan akan menimbulkan keguncangan karena hal tersebut telah menyimpang dari ketentuan yang ada.

Pernikahan usia dini akan menimbulkan dampak negatif ketika tidak dilandasi dengan niat yang sungguh-sungguh untuk melakukan pernikahan, seperti menurut Najib: "pernikahan di usia dini akan membawa dampak negatif bagi kehidupan kedua belah pihak pasangan, apabila mereka memasuki kehidupan berumah tangga tidak dibekali dengan ilmu agama, dan kesiapan lahir batin. Sehingga pernikahan tersebut dapat menimbulkan terjadinya perceraian bagi kedua pasangan tersebut".

Berdasarkan wawancara diatas, Najib mengatakan pernikahan yang tidak dibekali ilmu agama dan kesiapan lahir batin, akan menimbulkan dampak negatif seperti perceraian.

Perceraian merupakan dampak negatif dari pernikahan usia dini. Namun dampak positif juga di harapkan dalam pernikahan usia dini, seperti Sumiati mengatakan: "Tidak semua pernikahan dini berdampak negatif. Pernikahan menghindari dari pergaulan seks bebas, kehidupan mereka selanjutnya tidak akan telantar. Dulu Sumiati salah satu pelaku pernikahan dini, dan tidak berdampak negatif bagi dia, bahkan sekarang pernikahan sudah dijalani selam 27 tahun dan dikaruniai 3 orang anak".

Berdasarkan wawancara diatas, Sumiati mengatakan bahwa kalau pernikahan dini tidak selamanya berdampak negatif. Pernikahan dapat menghindari pergaulan bebas.

Tingginya anak menikah di bawah umur disebabkan oleh faktor sosial, peran orang tua sangat penting bagi perkembangan anak. Kurangnya pengetahuan menyebabkan anak terjerumus kedalam pergaulan yang negatif, sehingga harus melakukan pernikahan di usia dini. Belum ditemukannya faktor dominan untuk mengatasi maraknya pernikahan dini, dengan perkembangan teknologi dan pergaulan yang bebas anak terjerumus kedalam pergaulan bebas.

Jadi, dapat disimpulkan bahwa faktor sosial yang menyebabkan terjadinya pernikahan dini di Desa Banajar Balam adalah pergaulan bebas. Faktor tersebut dapat kita kaitkan dengan penelitian Zulfadli (2016) dalam Priyanti (2013) bahwa ada hubungan antara pergaulan bebas dengan pernikahan dini pada remaja yang menikah di usia dini sebagai akibat pergaulan bebas. Pernyataan ini sangat sesuai, karena di Desa Banjar Balam faktor penyebab terjadinya pernikahan dini adalah pergaulan bebas.

Dapat juga dikaitkan dengan norma-norma yang berlaku dalam masyarakat. seperti norma agama, bahwa masyarakat Desa Banjar Balam bisa digolongkan taat pada agama. Seperti menikahkan anaknya untuk menghindari dari hal-hal yang negatif, kemudian norma kesusilaan merupakan kebiasaan yang ada pada masyarakat itu sendiri seperti menikahkan anaknya jika tidak lagi melanjutkan pendidikan dan norma hukum merupakan aturan yang berlaku sesuai adat istiadat yang berlaku dalam masyarakat Desa Banjar Balam seperti anak yang hamil diluar nikah harus dinikahkan secepatnya tanpa memikirkan dampak negatif 
dari pernikahannya. Sehingga remaja di Desa Banjar Balam belum dapat menerapkan norma-norma tersebut, kemudian remaja yang melakukan pernikahan dini belum memiliki pengetahuan dari dampak negatif tindakan mereka terhadap norma-norma yang ada di masyarakat. Mereka tidak merasa malu dan takut mengenai ini menurut mereka adalah hal yang sudah biasa

\section{Faktor Pendidikan}

Pendidikan merupakan salah satu penyebab sebagian remaja melakukan pernikahan dini, karena sebagian masyarakat yang berpendidikan dasar atau menengah lebih cenderung untuk dinikahkan oleh orang tuanya, dibandingkan dengan masyarakat yang berpendidikan tinggi, dalam kekosongan waktu tanpa pekerjaan membuat mereka akhirnya melakukan hal-hal yang negatif, salah satunya adalah menjalin hubungan dengan lawan jenis, yang jika diluar kontrol membuat kehamilan diluar nikah.

Tabel 1 Keadaan penduduk berdasarkan tingkat pendidikan

\begin{tabular}{ll}
\hline Tingkat Pendidikan & Jumlah \\
\hline Tingkat kanak-kanak (TK) & 21 \\
Sekolah Dasar (SD) & 615 \\
Sekolah Menengah Pertama (SLTP) & 143 \\
Sekolah Menengah Atas (SLTA) & 177 \\
Perguruan Tinggi (PT) & 25 \\
\hline
\end{tabular}

(Sumber: Profil Desa Banjar Balam, Kecamatan Lirik Tahun 2019)

Berdasarkan tabel di atas bahwa, Tingkat Pendidikan terbanyak adalah Sekolah Dasar (SD) sebanyak 615 orang yang hanya lulusan Tingkat Sekolah Dasar (SD). kemudian Tingkat Sekolah Menengah Atas (SMA) sebanyak 177 orang, Sekolah Menengah Pertama (SMP) sebanyak 143 orang, Perguruan Tinggi (PT) sebanyak 25 orang. Sedangkan yang paling sedikit adalah Tingkat Kanak-kanak (TK), hal ini menyebabkan banyak terjadinya pernikahan dini di Desa Banjar Balam.

Pergaulan bebas biasanya di awali dengan perilaku sering keluar rumah, terpengaruh teman sebaya, dan sering membolos pada jam sekolah. Hal ini sangat disayangkan, karena kebiasaan yang sudah dilakukan dari kecil akan menjadi suatu kebiasaan sampai dewasa nanti. Peran orang tua harusnya memberikan pemahaman mengenai pentingnya pendidikan, agar anaknya mengerti akibat apa saja yang ditimbulkan oleh pernikahan dini seperti mengenai kesehatan reproduksi pada anaknya. Anak harus disibukkan dengan kegiatan berkreasi dan berprestasi agar terjauh dari hal-hal yang menyebabkan pernikahan dini. Sama halnya dengan hasil Informan SN: "Sebenarnya saya sangat berharap melanjutkan pendidikan ke tingkat yang lebih tinggi, dikarenakan masalah biaya orang tua saya tidak bisa memenuhi harapan. Saya memutuskan untuk menikah, agar orang tua saya bisa membiayai pendidikan adik-adik saya".

Berdasarkan hasil wawancara diatas bahwa, SN melakukan pernikahan dini disebabkan oleh biaya. Sehingga SN putus sekolah dan memutuskan untuk menikah dini bertujuan untuk meringankan beban orang tuanya. Beda halnya dengan hasil informan IF: "Sebenarnya saya ingin sekali melanjutkan pendidikan yang lebih tinggi, dikarenakan saya dulu pas sekolah sering membolos demi bisa bertemu dengan pacar saya di luar sekolah. Saya dan pacar saling menyayangi hingga kami melakukan hal yang tidak sewajarnya kami lakukan mengakibatkan hamil. Saya sangat menyesal".

Berdasarkan hasil wawancara diatas bahwa, IF putus sekolah dikarenakan sering membolos sekolah dan memiliki hubungan spesial dengan kekasihnya. Sehingga terjadilah hal-hal yang tidak diinginkan yaitu hamil diluar nikah.

Tingginya anak menikah di bawah umur disebabkan oleh faktor pendidikan, bahwa anak kurang mendapatkan pengetahuan yang berdampak negatif terhadap pernikahan dini seperti alat reproduksi. Peran pemerintah dalam menindak lanjutkan permasalahan pernikahan dini yang sering terjadi di Desa Banjar Balam sangat di perlukan. Dengan memberikan sosialisasi dari puskesmas setempat agar anak bisa mengetahui apa saja dampak negatif dari pernikahan dini, sehingga faktor dominan untuk mengatasi maraknya pernikahan dini dapat diminimalisasikan.

Rendahnya Kesadaran Terhadap Pentingnya Pendidikan Orang tua maupun anak tidak memikirkan betapa pentingnya pendidikan bagi anak-anaknya untuk mencapai masa depan yang lebih baik. Pengetahuan orang tua maupun anak yang masih kurang, karena rendahnya pendidikan yang mereka miliki khususnya tentang seluk beluk sebuah perkawinan yang kekal dan abadi. Sehingga berlangsungnya sebuah perkawinan tidak mempertimbangkan umur anak yang masih di bawah umur. 
Dapat disimpulkan bahwa, faktor pendidikan yang menyebabkan terjadinya pernikahan dini adalah pergaulan bebas dan kurangnya pengetahuan tentang dampak negatif dari pernikahan dini. Dapat dikaitkan dengan teori menurut Zulfadli (2016), bahwa pendidikan sebagai sarana yang cukup baik dalam meminimalisir pernikahan usia anak terkhusus pada pendidikan anak dari orang tua tentang dampak bahaya dari pernikahan usia anak, rendahnya tingkat pendidikan anak, orang tua dan masyarakat. Sehingga mereka tidak paham tentang wajib sekolah 9 tahun.

Jadi penelitian mengenai faktor pendidikan akibat pernikahan dini yang terjadi di Desa Banjar Balam sesuai dengan pendekatan menurut Zulfadli (2016), karena kurangnya pengetahuan dan terjadinya pergaulan bebas remaja di Desa Banjar Balam.

\section{Faktor budaya}

Budaya merupakan kebiasaan yang sering terjadi pada masyarakat di perdesaan, adanya kecemasan orang tua akan anak gadisnya dekat dengan pria lain tanpa ikatan pernikahan sehingga mereka memilih menikahkan anaknya meski masih dalam usia dini. Hal ini sudah menjadi budaya di beberapa daerah, seperti di Desa Banjar Balam. Pergaulan yang tidak sehat memicu adanya pernikahan dini. Tingkat kemiskinan yang cukup rentan dengan ketimpangan pendapatan yang semakin melebar, salah satu penyebab seseorang putus sekolah dan memutuskan untuk menikah dini.

Sahara (2018), menyatakan bahwa penyumbang terbesar dalam angka pernikahan dini adalah daerah perdesaan dibandingkan perkotaan. Salah satu penyebab masih tingginya angka pernikahan dini adalah faktor sosial dan budaya yang masih mendominasi beberapa daerah di perdesaan. Sedangkan menurut Pohan (2017), menyatakan bahwa orang tua berperan dalam mengambil keputusan dan percaya dengan budaya-budaya yang masih ada di masyarakat. Sama halnya dengan hasil Informan SN: "Sebenarnya orang tua saya sangat mendukung agar saya cepat menikah, sebab saya tidak melanjutkan pendidikan lagi. Saya hanya lulusan Sekolah Menengah Pertama (SMP) saja".

Berdasarkan wawancara dengan informan SN, bahwa ia tidak melanjutkan pendidikan lagi. Ia hanya lulusan Sekolah menengah Pertama (SMP) dan memutuskan untuk menikah sangat di dukung oleh orang tuanya, agar kehidupan ia ke depan lebih baik lagi dan meringankan beban kedua orang tuanya. Kemudian hasil wawancara menurut bapak Orang Tua pelaku sebagai berikut:

"Dari zaman saya dulu, memang kalau anak perempuan itu yang tinggal di desa apa lagi tidak sekolah biasanya cepat menikah. Sepertinya sudah menjadi kebiasaan dan turun temurun, menurut saya itu hal biasa makanya saya menikahkan anak saya lebih cepat".

Berdasarkan wawancara dengan informan Bapak orang tua pelaku bahwa, kebanyakan perempuan yang tinggal di desa dan tidak sekolah lagi cepat untuk menikah. Hal itu sudah biasa terjadi, dan sudah turun temurun dari nenek moyang mereka, selain itu menurut hasil wawancara informan orang tua pelaku menyatakan bahwa: "Menurut orang tua zaman dulu, banyak anak itu banyak rezeki, jadi kalau anak saya ingin menikah lebih cepat itu lebih baik. Beban saya sebagai orang tua juga semakin ringan dan dapat menyekolahkan adik-adiknya".

Berdasarkan hasil wawancara dengan informan Bapak Basir bahwa, menikah dan memiliki keturunan yang banyak merupakan tradisi dari nenek moyang mereka terdahulu. Selain itu juga dapat meringankan beban orang tua sehingga bisa menyekolahkan adik-adiknya.

Tingginya anak menikah di bawah umur disebabkan oleh faktor budaya merupakan hal yang sudah biasa di Desa Banjar Balam, pentingnya peran pemerintah dalam menyosialisasikan tentang pernikahan dini di desa agar terwujudnya program pemerintah dalam mewujudkan kesejahteraan rakyat dengan menerapkan program Keluarga Berencana $(\mathrm{KB})$. sehingga faktor budya untuk mengatasi maraknya pernikahan dini dapat tercapai.

Dari hasil wawancara tersebut dapat di analisis bahwa kebiasaan masyarakat di desa masih sangat kental, seperti menikahkan anaknya lebih cepat di banding menyekolahkan anaknya ke jenjang yang lebih tinggi. Sedangkan keinginan anak tersebut belum ingin menikah hanya dikarenakan keterbatasan ekonomi ia rela menghabiskan masa mudanya untuk membahagiakan kedua orang tuanya.

Dapat disimpulkan bahwa, faktor budaya dari pernikahan dini di Desa Banjar Balam masih sangat kental, dikarenakan adat istiadat nenek moyang dari masyarakat Desa Banjar Balam, jika anak gadis sudah tidak melanjutkan sekolah disegerakan untuk dinikahkan. Pernyataan tersebut bersumber dari salah satu orang tua pelaku informan $\mathrm{SN}$. 
Jadi penelitian tentang faktor budaya, sesuai dengan teori menurut Sahara (2018), bahwa penyumbang terbesar dalam angka pernikahan dini adalah daerah perdesaan dibandingkan perkotaan. Salah satu penyebab masih tingginya angka pernikahan dini adalah faktor sosial dan budaya yang masih mendominasi beberapa daerah di perdesaan. Kemudian berkesinambungan juga menurut Pohan (2017) bahwa, orang tua berperan dalam mengambil keputusan dan percaya dengan budaya-budaya yang masih ada di masyarakat.

\section{KESIMPULAN}

Faktor-faktor yang menyebabkan perkawinan di bawah umur di Desa Banjar Balam Kecamatan Lirik Kabupaten Indragiri Hulu Provinsi Riau Thun 2017-2918, dapat ditarik kesimpulan sebagai berikut:

Berdasarkan teori Soejono Soekanto mengenai pendekatan sosiologi bahwa faktor penyebabnya sebagai berikut; Faktor Ekonomi yaitu keluarga yang berada di bawah garis kemiskinan; faktor pergaulan sosial ialah akibat dari pergaulan bebas; faktor pendidikan ialah faktor pendidikan yang rendah; dan faktor budaya adalah faktor budaya setempat.

\section{Referensi}

Arimurti Intan, Ira Nurmala, (2017). Analisis pengetahuan perempuan terhadap prilaku melakukan perniakahan usia dini di Kecamatan Wonosari Kabupaten Bondowoso: Jurnal the indonesian journal of public health, hal 249-262

Daliyo, (1989). Pengantar Ilmu Hukum, Jakarta: Pt Gramedia

Jannah F, (2012). Pernikahan dini dan implikasinya terhadap kehidupan keluarga pada masyarakat madura: Jurnal Dikursus Islam Vol. 7 (No. 1)

Pohan Nazil W, (2012). Faktor yang berhubungan dengan pernikahan usia dini terhadap remaja putri: Jurnal Endurance 2 (3), October 2017, hal 424-435

Sahara, (2018). Faktor yang mempengaruhi keputusan wanita menikah di Sumatera Barat Sumatera: Jurnal Ecogen Volume 1, hal 640-647

Sugiyono,(2017). Metode Penelitian Kualitatif. Bandung: Alfabeta

Yanti, (2018). Analisis faktor penyebab dan dampak pernikahan dini di Kecamatan Kandis Kabupaten Siak: jurnal ibu dan anak, 6, hal 96-103

Zulfadli, (2016). Faktor-faktor terjadinya pernikahan usia anak di Kabupaten Pangkep: Jurnal Diskursus Islam Volume 04 Nomor 2

Latifatul Ana M, (2019), Pernikahan dini di Indoensia: Faktor dan peran pemerintah (presfektif penegakan dan perlindungan hukum bagi anak): widya yuridika jurnal hukum, volume 2 nomor 1

Website:

Kementrian Pemberdayaan Perempuan dan Perlindungan Anak (PPPA): https://www.kemenpppa.go.id

Pernikahan menurut KBBI: https://kbbi.web.id/nikah.html

Data Statistik Proporsi Perempuan Umur 20-24 yang berstatus kawin atau berstatus hidup bersama sebelum umur 15 tahun menurut provinsi (persen) Tahun 2015-2017 bahwa provinsi Riau: Prodeskel.binapemdes.kemendagri.go.id

Sumber Undang-Undang:

Undang-Undang tentang Perkawinan Nomor 1 Tahun 1974

Undang-Undang Republik Indonesia Nomor 35 Tahun 2014 tentang

Perlindungan Anak

Undang-Undang Nomor 20 Tahun 2003 tentang pendidikan

Sumber Internet:

Berita Kompas.com: 
Yulia Ulan Dari, dkk. Faktor-faktor penyebab pernikahan dini di Desa Banjar Balam Kecamatan Lirik Kabupaten Indragiri Hulu Provinsi Riau

Christofours Ristianto, 2017. Kontroversi Putusan MK soal Batas UsiaPernikahan:https://news.detik.com/berita/d-4342917/kontroversi-putusan-mk-soal-batas-usiapernikahan\#

Berita Detik.News:

Eva Safitri, 2018. MK Perintahkan DPR Revisi UU Perkawinan Soal Batas

Usia Menikah: https://news.detik.com/berita/d-4342030/soal-usia-pernikahan-m

k-nilai-uu-perkawinan-diskriminatif 